\section{Intergovernmental Committee for Migration}

In July, close to 10,000 refugees and nationals emigrated under the auspices of ICM. Among the 10,000 were 6,000 Indochinese, 2,000 Eastern Europeans, 620 Central Americans, 350 Western Europeans, 140 Africans and 70 Afghans. In addition, ICM arranged the transfer of 2,853 Indochinese refugees from the asylum areas of Southeast Asia to the Refugee Processing Centres at Bataan, Philippines $(2,778)$ and Galang, Indonesia (75).

There was a slight increase in the flow of Soviet Jews during July, with 167 arrivals in Vienna. Of this number, the highest monthly total thus far this year, 41 were resettled in Israel and the remaining 126 were transferred to Italy for resettlement processing to other countries.

The government of El Salvador asked ICM to assist in resettlement of Salvadoreans who could benefit from the new Amnesty Law and who chose to leave the country. By the end of July, ICM had moved 306 persons (85 to Australia and 221 to Canada).

\section{ICARA II}

ICARA II, the Second International Conference on Assistance to Refugees in Africa, will take place in Geneva from 21 to 23 of May, 1984.

\section{Tamils Displaced in Sri Lanka}

Rioting erupted on July 24, 1983 in Sri Lanka. As many as 25,000 Tamils remain "interned" in refugee camps established by the government of President Jayawardene in the aftermath of the recent wave of violence. Unofficial estimates are that over 500 Tamils have been killed and as many as 100,000 left homeless. Since early August, many of the homeless have moved or have been transported by the government from the camps to Jaffna in the north where the Tamils have a numeric majority.

Canadian Tamils, the Tamil Eelam Society of Canada and independent committees of people concerned for the well-being of friends and relatives in Sri Lanka approached the Canadian government with appeals for assistance to allow Tamils into Canada in order to escape the situation in Sri Lanka.

\title{
World News
}

\section{Fewer Vietnamese Rescued at Sea}

Fewer Vietnamese refugees are being rescued at sea than in previous years. Refugees continue to speak of many ships passing them by, the UN reports. Over the previous three years, $18 \%$ of all boat people arrivals were rescued at sea. This year only $6 \%$ have so far been rescued at sea. Numbers are increasing, however, and in June, 444 Vietnamese were taken on board by 20 passing ships.

\section{UNRWA News}

Robert Dillon, United States Ambassador to Lebanon, has been named the next Deputy CommissionerGeneral of UNRWA. He will succeed Alan Brown who is due to retire from UNRWA at the end of January 1984 after five years' service.

In June, UNRWA announced its appeal for $\$ 13$ million to rebuild destroyed Agency schools, clinics and offices, to reconstruct refugee camp roads and drains and to provide cash grants to allow 3,200 destitute families to repair or rebuild their homes.

The United Kingdom has pledged $\$ 500,000(\$ 764,500)$ towards these efforts. Japan pledged \$8 million for this year and Australia has contributed $\$ 1,268,000$.

\section{New UN Group Holds First Session}

The first session of a 25-member Group of Governmental Experts on International Co-operation to Avert New Flows of Refugees established by the General Assembly in 1981 was held this year from April 12 to 15 . Its mandate is to undertake a comprehensive review of the problem of averting new flows of refugees, with a view to developing recommendations on appropriate means of international cooperation in the field, having due regard to the principle of non-intervention in the internal affairs of sovereign states.

\section{Honolulu Meeting Focuses on Refugee Situation in Southeast Asia}

Representatives of the governments of Australia, Canada, Japan and the United States, as well as representatives of the UNHCR, held informal meetings in Honolulu, Hawaii, on August 1, 2 and 3 to discuss the current refugee situation in Southeast Asia. Participants gave their views of the situation in the area and covered a wide range of subjects including current rates of resettlement, refugee care and maintenance, voluntary repatriation, the Orderly Departure Program from Vietnam, anti-piracy efforts, number of persons in first asylum countries and the need for a renewed effort to broaden international participation in the Southeast Asian refugee program effort.

In this last regard, participants agreed to urge the UNHCR, which was recognized by all parties as the key coordinating agency in refugee relief, to maintain its efforts to secure the broadest degree possible of international participation in the resettlement and relief program for Southeast Asian refugees. All participants agreed that the long-term solution of the problem will require implementation of a mix of policies. In this context, the parties noted that voluntary repatriation was an important goal.

Participants also restated their commitment to the nations of first asylum to help solve the problem through the resettlement of, and provision of assistance to those refugees, until a humane and lasting solution to their plight could be achieved.

The countries represented believed it was important that those contemplating departure understood that the limited available resettlement opportunities were for refugees only.

The meeting was mindful of the burden on the countries of the region receiving the inflow. Their sustained humanitarian response was appreciated.

The representatives acknowledged the usefulness of, and need to continue, orderly departure opportunities to contain the problem.

Finally, they agreed to continue the process of consultations and to ask other interested countries to participate at future meetings. 